Article

\title{
Physiological, Biochemical, and Biometrical Response of Cultivated Strawberry and Wild Strawberry in Greenhouse Gutter Cultivation in the Autumn-Winter Season in Poland-Preliminary Study
}

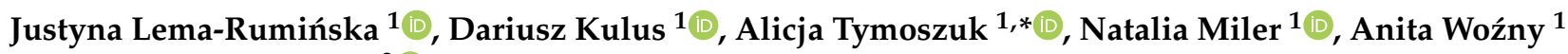 \\ and Anna Wenda-Piesik ${ }^{2}$ (D) \\ 1 Laboratory of Ornamental Plants and Vegetable Crops, Faculty of Agriculture and Biotechnology, \\ UTP University of Science and Technology, Bernardyńska 6, 85-029 Bydgoszcz, Poland; \\ lem-rum@utp.edu.pl (J.L.-R.); dkulus@gmail.com (D.K.); nmiler@utp.edu.pl (N.M.); \\ wozny@utp.edu.pl (A.W.) \\ 2 Department of Agronomics, Faculty of Agriculture and Biotechnology, UTP University of Science and \\ Technology, Kaliskiego 7, 85-796 Bydgoszcz, Poland; apiesik@utp.edu.pl \\ * Correspondence: alicja.tymoszuk@utp.edu.pl
}

check for updates

Citation: Lema-Rumińska, J.; Kulus, D.; Tymoszuk, A.; Miler, N.; Woźny, A.; Wenda-Piesik, A. Physiological, Biochemical, and Biometrical Response of Cultivated Strawberry and Wild Strawberry in Greenhouse Gutter Cultivation in the

Autumn-Winter Season in Poland-Preliminary Study. Agronomy 2021, 11, 1633. https:// doi.org/10.3390/agronomy11081633

Academic Editors: Gianluca Baruzzi and Giancarlo Roccuzzo

Received: 21 July 2021

Accepted: 13 August 2021

Published: 17 August 2021

Publisher's Note: MDPI stays neutral with regard to jurisdictional claims in published maps and institutional affiliations.

Copyright: (c) 2021 by the authors. Licensee MDPI, Basel, Switzerland. This article is an open access article distributed under the terms and conditions of the Creative Commons Attribution (CC BY) license (https:/ / creativecommons.org/licenses/by/ $4.0 /)$.

\begin{abstract}
Strawberry and wild strawberry are among the most popular horticultural crops. Due to the development of soilless cultivation systems, the whole-year production of these economically important fruit crops is achievable even in countries with temperate climate. However, the responses of strawberry (Fragaria $\times$ ananassa Duch.) and wild strawberry (Fragaria vesca L.) to microclimate conditions in greenhouse gutter cultivation in the autumn-winter season in Poland have not been yet determined. The aim of this study was to analyze the physiological, biochemical, and biometrical responses of two cultivars of strawberry 'Ostara' and 'San Andreas' and two cultivars of wild strawberry 'Baron von Solemacher' and 'Regina' grown for 20 weeks, starting from September 17 th, in controlled greenhouse conditions on coconut mats in gutters in the autumn-winter season and irradiated with sodium lamps. Strawberry 'San Andreas' produced 30\% larger leaves and almost three-fold higher fresh and dry weight of biomass than 'Ostara'. The strawberry plants 'San Andreas' had a higher content (20\%) of chlorophyll $a$ and 30\% of chlorophyll $b$ than 'Ostara' plants. Generally, 'San Andreas' displayed an overall higher concentration of intercellular $\mathrm{CO}_{2}$ (about 14\%) than 'Ostara' plants providing higher gas exchange processes. Photosynthetic rate amounted to $13.0 \mu \mathrm{mol} \cdot \mathrm{m}^{-2} \cdot \mathrm{s}^{-1}$ for 'San Andreas' that was almost two-fold higher than for 'Ostara'. 'San Andreas' flower and fruit productions were uniform and the six-fold higher individual fruit yield proved the excellent attributes of this cultivar to the greenhouse cultivation. Even though the productivity of the two studied wild strawberry cultivars was similar, 'Regina' showed higher values of some parameters than 'Baron von Solemacher' (40\% larger leaves, 25\% higher photosynthetic rate, $10 \%$ higher concentration of intercellular $\mathrm{CO}_{2}$ ). A high nutritional value of fruits is maintained compared to traditional open-air cultivation.
\end{abstract}

Keywords: Fragaria $\times$ ananassa; Fragaria vesca; anthocyanins; carotenoids; chlorophylls; gas-exchange; flowering; fruit; growth; photosynthesis; polyphenols; total carbohydrates

\section{Introduction}

Fruit berries, especially strawberry and wild strawberry (Rosaceae), belong to the most popular horticultural crops. They have delicious taste and aroma, high economic importance, low calorific value, and are of great interest for nutritionists and food technologists because they are often consumed in fresh form when the most bioactive compounds are still active and in the greatest amount [1]. Poland is an important global producer of strawberries (47.9 thousand hectares), ranking second just after China (111 thousand 
hectares) [2]. Octoploid cultivated strawberries (Fragaria $\times$ ananassa Duch.) and diploid wild or wood strawberries (Fragaria vesca L.) are consumed in high quantities (the yield of strawberry is the 7th largest in the world) [3] and are thus a valuable source of ascorbic acid, potassium, fiber, simple sugars, as well as antioxidants, such as phenolics, anthocyanins, and other flavonoid compounds [4-6]. Although yield is commonly the main focus of berries production, consumers demand more and more often fruits with higher phytochemical properties [7]. Consumption of berries of the Rosaceae family is shown to lower the risk for chronic diseases like inflammation disorders, cancer, cardiovascular and obesity-related disorders, and stroke [8]. Consequently, numerous studies on the cultivation, physiology, and health-promoting properties of (wild) strawberry are performed.

Two main categories of wild and cultivated strawberry exist: (1) short-day seasonal flowering genotypes which initiate flower buds either under short-day conditions (day length less than $14 \mathrm{~h}$ ) or at a temperature less than $15^{\circ} \mathrm{C}$ and produce only one flush of flowering and fruiting in the spring; and (2) long-day recurrent flowering or everbearing genotypes which, in addition to a spring flush, produce more or less continuous flowering and fruiting throughout the growing season. Although temperature modifies the photoperiodic responses of these plants, they are less sensitive to high temperatures than short-day plants $[9,10]$.

Consequently, the cultivation of (wild) strawberry can be performed either outdoors or indoors. Due to the growing demand of developed countries for year-round fresh fruits, many producers are shifting from traditional open-field cultivation to greenhouses [11,12]. Therefore, information about the agronomic performance of (wild) strawberry cultivars in greenhouse conditions is widely required to help producers in choosing the best cultivars for this application [7]. Soilless growing systems, such as gutter cultivation, have several advantages over traditional cultivation in the soil, which is limited due to the ergonomic difficulties of cultivating the plants on the ground surface and the prohibition of chemical fumigants for the control of phytopathogens [13]. Protected cultivation has provided efficient ways to overcome potentially harmful outdoor conditions such as low and high solar radiation, extreme temperatures, wind, heavy rain, frost, and hail. Moreover, the greenhouse environment can be easily controlled with the required water vapor, $\mathrm{CO}_{2}$ concentration, and airflow conditions [14,15]. Consequently, an extension of the harvesting period and fruit quality improvement are observed [16]. The technology of soilless cultivation attracts producers due to easier fertility control, the possibility of increasing plant density and yield, a decrease in diseases and pests, and the increment in the product quantity and quality [17]. Production of plants in closed fertigation systems and coconut fibre substrate is the current trend for the cultivation of (wild) strawberry. When cultivation is carried out on benches above ground level, the work is easier, the use of fumigant soil products is eliminated, and there is a reduction in the occurrence of leaf diseases and, consequently, in the application of pesticides [13]. To prevent crops from suffering damage caused by the shortage of sunlight, the introduction of supplementary light into the cultivation practice is necessary. Various light sources-such as incandescent, fluorescent, metal halide, or high-pressure sodium lamps (HPS) or light-emitting diodes (LEDs) - were adopted as supplementary lights for the cultivation of strawberry plants [18].

Environmental factors-such as light, water, $\mathrm{CO}_{2}$, temperature, and nutrients-are important elements in the production of high-quality berries [18]. The physiology of (wild) strawberry growth and flowering is complex because of the great variability of the plant behavior in response to climate conditions, and the genetic background of the cultivar $[1,10]$. Those factors directly affect the biosynthesis of essential metabolites in fruits and leaves [4].

The health-promoting properties of fruits are a result of a unique composition of bioactive compounds, including polyphenols, which are characterized by a high antioxidant activity. The presence and quantity of polyphenols have been used as markers allowing the distinction between cultivars. Fruits may vary in terms of the composition of polyphenols depending on the cultivar, growing conditions, and ripeness stage. The dominant group 
of polyphenols in (wild) strawberry fruit are anthocyanins with pelargonidin-3-glucoside being the major one [19].

Chlorophylls and carotenoids fulfill various vital functions in plants. In the chloroplast, chlorophylls are the predominant light-absorbing pigment in photosynthesis, and carotenoids are an important component required for light-harvesting and photoprotection $[20,21]$. A physiological performance, especially $P_{N}$ and $G s$, are related to the leaf thickness and chlorophyll content as the increase in these parameters enable the plant to absorb more light, particularly in the range of photosynthetically active radiation (PAR), and convert light energy into chemical energy [22,23]. Besides the essential function as photoprotectants, carotenoids act as oxidative stress 'sensor' and 'signal' upon oxidation by reactive oxygen species (ROS) [24]. Oxidative stress is an integral component of various stress conditions in plants, and this fact mainly determines the substantial overlap in physiological and molecular responses to biotic and abiotic environmental challenges [25]. Moreover, derivatives of chlorophylls and carotenoids consumed with berry fruits are consistent with cancer prevention in humans including antioxidant and antimutagenic activity [26,27]. Photosynthesis is inextricably linked to the physiology of the entire plant through mutual controls. A metabolic signal network including information on the carbon and nitrogen status of tissues interacts with phytohormone signaling and redox signaling to control photosynthetic gene expression and leaf development [28].

The availability of fresh fruit on the European market throughout the year is varied; i.e., in the autumn and winter season, fresh fruits of (wild) strawberries from local markets are often unavailable, or their taste is worse than that of fruits grown in the spring. Extending the harvest period would allow for a year-round consumption of fresh strawberries from domestic productions and an increase in the producers' income [29]. Only the development of greenhouse technologies, including gutter cultivation, gives a chance to lower production costs in colder climatic zones. Therefore, it is desirable to develop research on the physiological, biochemical, and biometrical activities of strawberry and wild strawberry in the autumn-winter gutter cultivation. The selection of the most suitable cultivars for this purpose is also needed.

Each strawberry and wild strawberry cultivar has its growth and yield characteristics [15]. However, the response of many cultivars to microclimate conditions in gutter cultivation in greenhouses has not been yet determined. Therefore, the objective of this study was to determine the physiological, biochemical, and biometrical responses of two strawberry and two wild strawberry cultivars.

The research hypothesis assumed that among the various cultivars of these two plant species, it is possible to select those that have better biological and physiological attributes for greenhouse gutter cultivation in the autumn-winter season in Poland.

\section{Materials and Methods}

\subsection{Plant Material, Cultivation Conditions, and Evaluation of Crop Productivity}

Potted plants of two cultivars of strawberry (everbearing 'Ostara' and day-neutral 'San Andreas') and two cultivars of wild strawberry ('Baron von Solemacher' and 'Regina') were used in the study (Figure 1). The experiment was set in a greenhouse of the Laboratory of Ornamental Plants and Vegetable Crops at the Faculty of Agriculture and Biotechnology of the UTP University of Science and Technology in Bydgoszcz, Poland, $\left(53^{\circ} 07^{\prime} 12.0^{\prime \prime} \mathrm{N}\right.$ $18^{\circ} 00^{\prime} 29.4^{\prime \prime} \mathrm{E}$ ) in the period from 17 September 2020 to 4 February 2021. The experiment was set in two gutters (Figure 1A), with each gutter used for the separate cultivation of strawberry and wild strawberry. Eight plants of each cultivar studied were planted every $12.5 \mathrm{~cm}$ on coconut mats ( $1 \mathrm{~m}$ long). Each cultivar was grown on five mats, with a total of 40 individual plants available. An alternating distribution of cultivars in the gutter was used. The coconut mats were pre-rinsed with water through a fertigation system to remove excess salt. Both the substrate and the filtrate were subjected to chemical analysis of impurities. In the period from 14 October 2020 until the end of the experiment, the plants were additionally irradiated with HPS lamps (LeuTech 600W, Thörigen, Switzerland) for 
two to six hours from 2 p.m. The mean photosynthetic photon flux density (PPFD) was $100 \mu \mathrm{mol} \cdot \mathrm{m}^{-2} \cdot \mathrm{s}^{-1}$. The temperature in the greenhouse was $18.5^{\circ} \mathrm{C}$ day $/ 15.5^{\circ} \mathrm{C}$ night. Plants were fertigated 2-3 times a week delivering a total of $230 \mathrm{~mL}$ medium per two plants per day. Terms of fertigation doses were established according to tensiometer indications. Fertigation was started when the water potential in the soil was $-40 \mathrm{kPa}$. The nutrient solution had an EC of $1.3 \mathrm{mS} \mathrm{cm}^{-1}$ and a pH of 5.5 during the vegetative growth of plants. When the plants started flowering, the EC was raised to $2.2 \mathrm{mS} \cdot \mathrm{cm}^{-1}$ at a $\mathrm{pH}$ of 5.5-6.0.
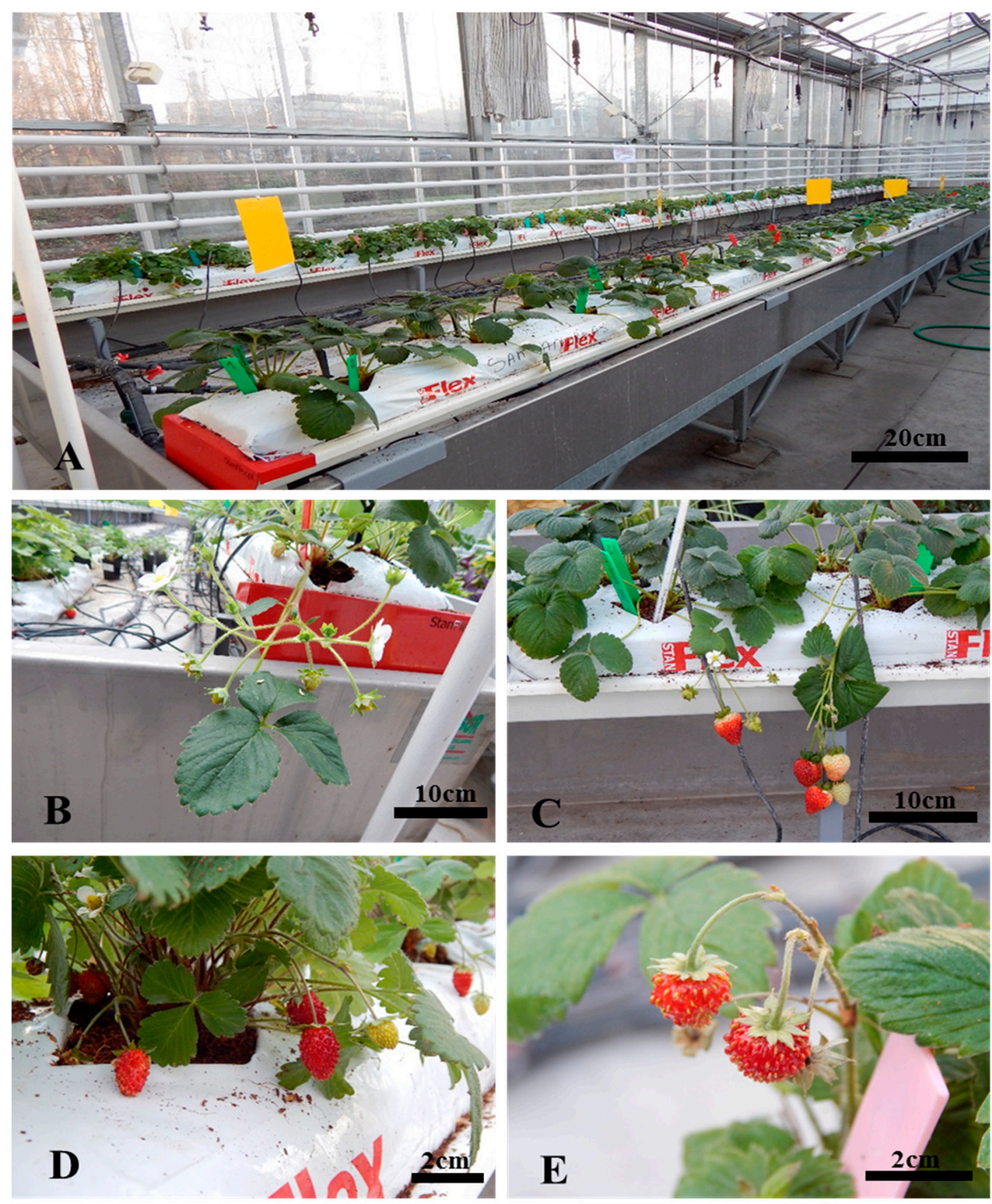

Figure 1. Strawberry and wild strawberry gutter cultivation in the autumn and winter season (A), 'Ostara' (B), 'San Andreas' (C), 'Baron von Solemacher' (D), ‘Regina' (E).

Starting from 1 December, weekly observations and measurements were made regarding the number of produced shoots, flowers, and fruits. Based on weekly measurements of these parameters, graphs were created and trend lines were added according to the polynomial algorithm. The fresh weight (FW) of mature fruit was also considered. 
At the end of the experiment, leaves were collected from rosettes and scanned (Epson STD4800 scanner, USA). Next, the obtained pictures were analyzed to measure the mean leaf area $\left(\mathrm{cm}^{2}\right)$, maximal leaf horizontal width $(\mathrm{cm})$, maximal leaf vertical length $(\mathrm{cm})$, and leaf perimeter $(\mathrm{cm})$ using the imaging software WinFOLIA ${ }^{\mathrm{TM}}$ (Reagen Instruments, Quebec, QC, Canada). Fresh weight (FW) and dry weight (DW) (g) of leaves were also determined.

\subsection{Gas-Exchange Measurements}

The main gas-exchange parameters, net photosynthetic rate $\left(P_{N}\right)$, transpiration rate $(E)$, stomatal conductance $\left(g_{s}\right)$, and intercellular carbon dioxide $\left(\mathrm{CO}_{2}\right)$ concentration $(\mathrm{C} i)$ were measured at the center of the leaflet area, the leaves were fitted into a $6.25 \mathrm{~cm}^{2}$ clamp-on Plant Leaf Chamber (PLC Broad with mixed Red/Blue LED array). Gas exchange measurements lasted $20 \mathrm{~min}$. This was performed using a portable open infrared $\mathrm{CO}_{2}$ gas analyzer (LC-Pro+, ADC BioScientific Ltd., Hoddesdon, UK) between 10.00 a.m. and 2:00 p.m. The system allowed for an automated microclimate control in the PLC. The conditions were stable in PLC and amounted to light $600 \mu \mathrm{mol} \cdot \mathrm{m}^{-2} \cdot \mathrm{s}^{-1}, \mathrm{CO}_{2}$ concentration $360 \pm 5$ ppm; temperature $22 \pm 1^{\circ} \mathrm{C}$, water vapor pressure $10 \pm 1$ mbar (relative humidity approximately $40 \%$ ). The rate of airflow through the LCpro+ chamber was approximately $200 \mathrm{~mL} \cdot \mathrm{min}^{-1}$. In the growth chamber where the gas-exchange parameters were measured, the oxygen concentration was ambient (21\%). Each parameter was measured twice, at stages BBCH 61 (flowering stage) and BBCH 85 (mature fruit stage) at 20 individuals for both species and cultivars.

\subsection{Biochemical Analysis of Leaves and Fruits}

Carotenoids and anthocyanins were extracted from fresh leaves or fruits (100 or $200 \mathrm{mg}$ of fresh tissue, respectively) according to the procedure described by LemaRumińska and Zalewska [30]. The total contents of carotenoids and anthocyanins were calculated with the coefficient obtained from the Wettstein [31] or Harborne [32] equation, respectively. Chlorophyll $a$ and $b$ were extracted from fresh leaves according to Lichtenthaler and Buschmann [33] using 100\% acetone and $100 \mathrm{mg}$ of fresh tissue samples. Carbohydrates were extracted from $100 \mathrm{mg}$ fresh fruit samples with $2.5 \mathrm{M} \mathrm{HCl}$. The quantification of total carbohydrate content was based on the anthrone test [34]. The same extract was used to analyze the total phenolic content, according to the Folin-Ciocalteau procedure [35].

The spectral analysis of extracts was performed in a UV-VIS spectrophotometerShimadzu UV 1601-PC (Kioto, Japan) and SmartSpec PlusTM (BioRad, Hercules, CA, USA) in a quartz cuvette $(1 \mathrm{~cm})$ at specific wavelengths $\left(\lambda_{\max }\right)$ : for carotenoids at $440 \mathrm{~nm}$, for anthocyanins at $530 \mathrm{~nm}$, for chlorophyll $a$ and $b$ at 645 and $662 \mathrm{~nm}$, for carbohydrates at $620 \mathrm{~nm}$, and for phenolics at $765 \mathrm{~nm}$. The carbohydrate and phenolic contents were calculated using glucose and gallic acid as the calibration standards, respectively. The content of pigments, carbohydrates, and phenolics was calculated per gram of fresh weight. The biochemical analysis was performed in ten repetitions.

\subsection{Statistical Analysis}

Data obtained for all the physiological, biochemical, and biometrical characteristics of strawberry and wild strawberry were checked for normality using the Shapiro-Wilk test and the stability of variance with Levene's test in the groups of cultivars. Verification of null hypotheses regarding the effects of growth stage and cultivars was carried out based on the two-way ANOVA, $F$ test for $p<0.05$. For the proven effects of the experimental factors on the physiological parameters in strawberry and wild strawberry, testing of the differences between the mean values was performed with the use of the HSD post-hoc Tukey's test at the level of $p<0.05$. The differences between cultivars in biochemical, and biometrical parameters were tested using the $t$-Student test, at $p=0.05$. $r$-Pearson's simple correlation coefficients and linear regressions were estimated between values of $C i$ and 
$P_{N} / E$ parameters for both species. The Statistica 13 (StatSoft, Cracow, Poland) software package was used for all the analyses.

\section{Results}

3.1. The Dynamics of Flowering and Yielding, and Biometrical Leaf Characteristic of Strawberry and Wild Strawberry

Weekly observations of strawberry and wild strawberry showed differences in the dynamics of their flowering and yielding. Strawberry 'Ostara' produced from two to nine flowers weekly, with a high fluctuation between two consecutive weeks (Figure 2A). The efficiency of fruit formation dropped after the 17th week of cultivation (Figure 2B). Moreover, fruits degenerated without maturing (Figure 2C,D), which resulted in a very low total yield of less than one mature fruit per plant. As for strawberry 'San Andreas', the flower and fruit production were more uniform during the cultivation period, and even a slight increase in flower formation was observed in the last three weeks. Most fruits matured, although the overall productivity was also limited (Figure 2A-D).

The dynamics of weekly flower and fruit formation in wild strawberries were similar in both cultivars. Starting from the 17th week of cultivation, the number of flowers and, consequently, fruits decreased. It was observed that the mean yield of mature fruits per plant was uniform starting from January. Moreover, there were no differences in terms of both productivity and fruit fresh weight in the two wild strawberry cultivars.

The performed statistical analysis of leaf biometrical measurements revealed that strawberry 'San Andreas' produced leaves with the larger area, maximal vertical length, and perimeter compared to 'Ostara' cultivar (Table 1). The values of these parameters were as follows: 37.99 and $24.91 \mathrm{~cm}^{2} ; 11.32$ and $7.41 \mathrm{~cm} ; 41.94$ and $31.29 \mathrm{~cm}$, respectively, for 'San Andreas' and 'Ostara'. Moreover, the leaves of 'San Andras' cultivar had an almost three-fold higher fresh and dry weight ( $3.01 \mathrm{~g}$ and $0.93 \mathrm{~g}$, respectively); whereas the values for 'Ostara' were $1.10 \mathrm{~g}$ and $0.36 \mathrm{~g}$, respectively.

Table 1. Biometrical characteristic of leaves of two strawberry cultivars.

\begin{tabular}{ccccccc}
\hline Cultivar & Area $\left(\mathbf{c m}^{\mathbf{2}}\right)$ & $\begin{array}{c}\text { Horizontal } \\
\text { Width } \mathbf{( c m})\end{array}$ & $\begin{array}{c}\text { Vertical Length } \\
(\mathbf{c m})\end{array}$ & Perimeter $(\mathbf{c m})$ & FW (g) & DW (g) \\
\hline San Andreas & $37.99 \pm 24.58 \mathrm{a}$ & $7.57 \pm 2.49 \mathrm{a}$ & $11.32 \pm 3.48 \mathrm{a}$ & $41.94 \pm 14.97 \mathrm{a}$ & $3.01 \pm 0.85 \mathrm{a}$ & $0.93 \pm 0.26 \mathrm{a}$ \\
Ostara & $24.91 \pm 7.46 \mathrm{~b}$ & $6.09 \pm 1.40 \mathrm{a}$ & $7.41 \pm 2.14 \mathrm{~b}$ & $31.29 \pm 7.08 \mathrm{~b}$ & $1.10 \pm 0.30 \mathrm{~b}$ & $0.36 \pm 0.10 \mathrm{~b} 1$ \\
\hline
\end{tabular}

${ }^{1}$ Various letters in rows indicate significant differences according to the $t$-Student test at $p=0.05$.

The two tested cultivars of wild strawberry differed in terms of leaf biometrical parameters, such as leaf area, maximal horizontal and vertical length, and perimeter (Table 2). The values of all these parameters were higher in 'Regina' cultivar than in 'Baron von Solemacher', e.g., leaf area reached 18.41 and $10.53 \mathrm{~cm}^{2}$ and leaf perimeter was 37.98 and $20.74 \mathrm{~cm}$, respectively. Interestingly, no statistically important differences were found for leaf fresh and leaf dry weights between 'Baron von Solemacher' and 'Regina' cultivars.

Table 2. Biometrical characteristic of leaves of two wild strawberry cultivars.

\begin{tabular}{ccccccc}
\hline Cultivar & Area $\left(\mathbf{c m}^{2}\right)$ & $\begin{array}{c}\text { Horizontal } \\
\text { Width }(\mathbf{c m})\end{array}$ & $\begin{array}{c}\text { Vertical Length } \\
(\mathbf{c m})\end{array}$ & Perimeter $(\mathbf{c m})$ & FW (g) & DW $(\mathbf{g})$ \\
\hline $\begin{array}{c}\text { Baron von } \\
\text { Solemacher } \\
\text { Regina }\end{array}$ & $10.53 \pm 4.58 \mathrm{~b}$ & $3.56 \pm 1.12 \mathrm{~b}$ & $5.35 \pm 1.35 \mathrm{~b}$ & $20.74 \pm 5.72 \mathrm{~b}$ & $0.59 \pm 0.18 \mathrm{a}$ & $0.18 \pm 0.04 \mathrm{a}$ \\
\hline
\end{tabular}

\footnotetext{
${ }^{1}$ Various letters in rows indicate significant differences according to the $t$-Student test at $p=0.05$.
} 

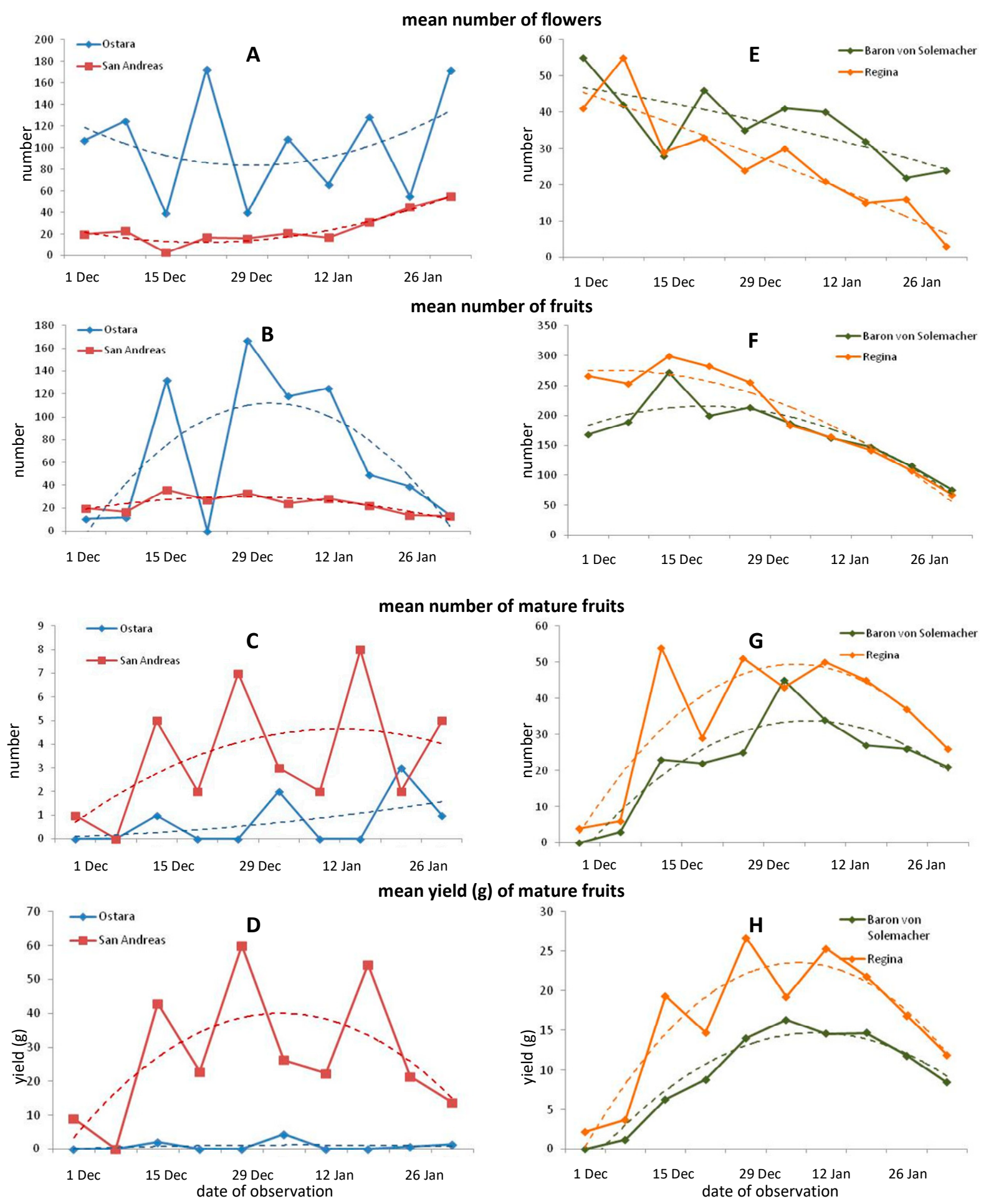

Figure 2. Flowering and yield data from weekly measurements in strawberry (A-D) and wild strawberry (E-H). (A) and (E) — mean number of flowers per plant; (B,F)—mean number of fruits per plant; $(\mathbf{C}, \mathbf{G})$ - mean number of mature fruits per plant; $(\mathbf{D}, \mathbf{H})$ - mean fresh weight $(\mathrm{g})$ of the mature fruit. Dotted lines represent polynomial trends for particular parameters and cultivars. 


\subsection{Physiological Response of Strawberry and Wild Strawberry}

Stomatal conductance amounted to $0.100 \mathrm{~mol} \cdot \mathrm{m}^{-2} \cdot \mathrm{s}^{-1}$ for both 'San Andreas' and 'Ostara' strawberry plants at $\mathrm{BBCH} 61$ stage, and $0.059-0.080 \mathrm{~mol} \cdot \mathrm{m}^{-2} \cdot \mathrm{s}^{-1}$ at $\mathrm{BBCH} 85$ stage (Table 3). The decrease of $g_{s}$ between the two stages was significant by $41 \%$ in 'San Andreas'. The concentration of intercellular $\mathrm{CO}_{2}(\mathrm{C} i)$ was significantly higher in 'San Andreas' plants at BBCH 50 stage and amounted to $324 \mu \mathrm{mol} \cdot \mathrm{mol}^{-1}$, and $227.4 \mu \mathrm{mol} \cdot \mathrm{mol}^{-1}$ for 'Ostara' plants. After 14 days, a significant 30\% decrease of $C_{i}$ was noted for 'San Andreas' leaf, in contrast to the nonsignificant $8.1 \%$ in 'Ostara' plants. Generally, 'San Andreas' displayed an overall higher concentration of intercellular $\mathrm{CO}_{2}$ than 'Ostara' plants, by about $14 \%$. Strawberry 'San Andreas' performed higher gas exchange processes than 'Ostara' plants. Photosynthetic rate amounted to $13.0 \mu \mathrm{mol} \mathrm{m}{ }^{-2} \cdot \mathrm{s}^{-1}$ for 'San Andreas' and $7.25 \mu \mathrm{mol} \mathrm{m}{ }^{-2} \cdot \mathrm{s}^{-1}$ for 'Ostara'. Moreover, the transpiration and net photosynthetic rate tendencies were similar in both cultivars of strawberry in the two periods studied. The decrease of $P_{\mathrm{N}}$ was accompanied by the decrease of $E$ between stages $\mathrm{BBCH} 61$ and $\mathrm{BBCH}$ 85; however, with 'Ostara', the transpiration has been stabilized at the level of $1.409 \mathrm{mmol} \cdot \mathrm{m}^{-2} \cdot \mathrm{s}^{-1}$, and in 'San Andreas' at $1.281 \mathrm{mmol} \cdot \mathrm{m}^{-2} \cdot \mathrm{s}^{-1}$.

Table 3. Gas-exchange parameters at two growing stages $(1-\mathrm{BBCH} 61 ; 2-\mathrm{BBCH} 85)$ of two strawberry cultivars.

\begin{tabular}{|c|c|c|c|c|c|c|c|c|c|}
\hline Cultivar & Stage & $\begin{array}{c}g_{s} \\
\left(\mathrm{~mol} \cdot \mathrm{m}^{-2} \cdot \mathrm{s}^{-1}\right)\end{array}$ & & $\begin{array}{c}C i \\
\left(\mu \mathrm{mol} \cdot \mathrm{mol}^{-1}\right)\end{array}$ & & $\underset{\left(\mu \mathrm{mol} \cdot \mathrm{m}^{-2} \cdot \mathrm{s}^{-1}\right)}{P_{N}}$ & & $\begin{array}{c}E \\
\left(\mathrm{mmol} \cdot \mathrm{m}^{-2} \cdot \mathrm{s}^{-1}\right)\end{array}$ & \\
\hline \multirow{2}{*}{ San Andreas } & 1 & $0.100 \pm 0.005$ & $\mathrm{a}$ & $324.3 \pm 16.3$ & $\mathrm{a}$ & $16.9 \pm 6.28$ & $\mathrm{a}$ & $1.569 \pm 0.052$ & $\mathrm{a}$ \\
\hline & 2 & $0.059 \pm 0.005$ & $\mathrm{~b}$ & $227.4 \pm 12.7$ & $\mathrm{~b}$ & $9.13 \pm 4.93$ & $\mathrm{~b}$ & $0.993 \pm 0.065$ & $\mathrm{~b}$ \\
\hline Mean & & $0.080 \pm 0.030$ & A & $275.8 \pm 12.8$ & A & $13.0 \pm 3.96$ & $\mathrm{~A}$ & $1.281 \pm 0.062$ & A \\
\hline \multirow{2}{*}{ Ostara } & 1 & $0.100 \pm 0.047$ & $\mathrm{a}$ & $247.8 \pm 16.5$ & $\mathrm{a}$ & $9.29 \pm 6.09$ & $\mathrm{a}$ & $1.552 \pm 0.102$ & $\mathrm{a}$ \\
\hline & 2 & $0.080 \pm 0.026$ & $\mathrm{a}$ & $227.5 \pm 14.6$ & $\mathrm{a}$ & $5.22 \pm 2.51$ & $\mathrm{~b}$ & $1.267 \pm 0.070$ & $\mathrm{a}$ \\
\hline Mean & & $0.090 \pm 0.039$ & A & $237.5 \pm 11.0$ & B & $7.25 \pm 3.27$ & B & $1.409 \pm 0.065$ & $\mathrm{~A}^{1}$ \\
\hline
\end{tabular}

$g_{s}$-stomatal conductance, $\mathrm{C} i$-intercellular carbon dioxide $\left(\mathrm{CO}_{2}\right)$ concentration, $P_{N}$-net photosynthetic rate, $E$ - transpiration rate;

${ }^{1}$ various letters in rows indicate significant differences between growing stages (small letters)/cultivars (large letters) according to HSD

Tukey's test at $p=0.05$.

Directional convergence of the two processes was confirmed by the coefficient of correlation ( $r$-Pearson) and linear regression (Figure 3). At the BBCH 61 stage, a significant and positive correlation was found between the concentration of intercellular $\mathrm{CO}_{2}$ and photosynthetic rate for 'San Andreas' $(r=0.70, p<0.001$ with the slope $b=0.062)$, and for 'Ostara' ( $r=0.38, p=0.05$ with the slope $b=0.068)$. Stabilization of the processes was observed between $C_{i}$ and transpiration rate, with a nonsignificant correlation between them in both cultivars studied at $\mathrm{BBCH} 85$ stage. The same pattern for both cultivars with increasing correlations between $\mathrm{C}_{\mathrm{i}}$ and $\mathrm{P}_{N} / \mathrm{E}$ was noted at $\mathrm{BBCH} 85$ stage with the $r=0.56-0.57$ for 'San Andreas' and $r=0.26-0.47$ for 'Ostara'.

Two cultivars of wild strawberry 'Baron von Solemacher' and 'Regina' displayed the same pattern of stomatal conductance, which amounted to $0.144 \mathrm{~mol} \cdot \mathrm{m}^{-2} \cdot \mathrm{s}^{-1}$ at $\mathrm{BBCH}$ 61 stage and $0.055-0.062 \mathrm{~mol} \cdot \mathrm{m}^{-2} \cdot \mathrm{s}^{-1}$ at BBCH 85 stage (Table 4). The decrease of $g_{s}$ at the two stages was significant for both cultivars by $57 \%$. The mean transpiration rate amounted to $1.517 \mathrm{mmol} \cdot \mathrm{m}^{-2} \cdot \mathrm{s}^{-1}$ for 'Baron' and $1.480 \mathrm{mmol} \cdot \mathrm{m}^{-2} \cdot \mathrm{s}^{-1}$ for 'Regina', respectively. The tendency of decreasing $E$ for the wild strawberry leaf was similar for both cultivars between BBCH 61 and BBCH 85 and reached $44 \%$ for 'Baron von Solemacher' and $49 \%$ for 'Regina'.

The concentration of intercellular $\mathrm{CO}_{2}(\mathrm{C} i)$ was significantly higher in 'Regina' wild strawberry plants and amounted to $269.1 \mu \mathrm{mol} \cdot \mathrm{mol}^{-1}$ overall in two stages, and $247.5 \mu \mathrm{mol} \cdot \mathrm{mol}^{-1}$ in 'Baron von Solemacher' plants. As for 'Regina', the concentration of intercellular $\mathrm{CO}_{2}$ dropped by $16 \%$ between BBCH 61-85. Accordingly, 'Regina' displayed an overall higher photosynthetic rate than 'Baron von Solemacher' by $25 \%$. 

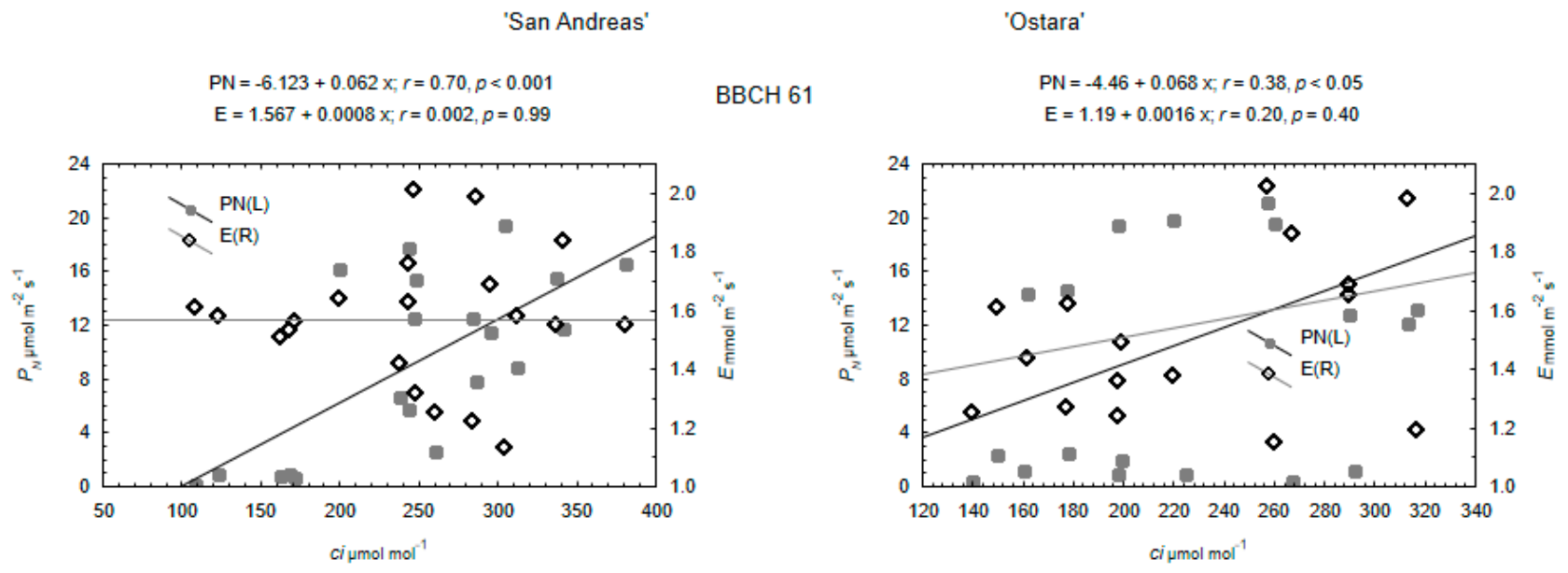

$\mathrm{PN}=-6.624+0.059 \times, r=0.57, p<0.01$

$E=0.422+0.003 x ; r=0.56, p<0.01$

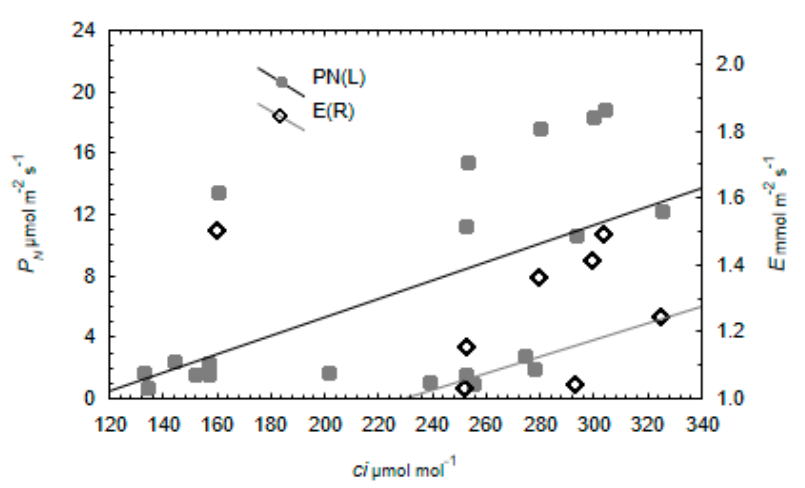

$\mathrm{BBCH} 85$

$$
\begin{gathered}
\mathrm{PN}=3.23+0.017 \times ; r=0.26, p>0.05 \\
\mathrm{E}=0.61+0.002 \times ; r=0.47, p=0.03
\end{gathered}
$$

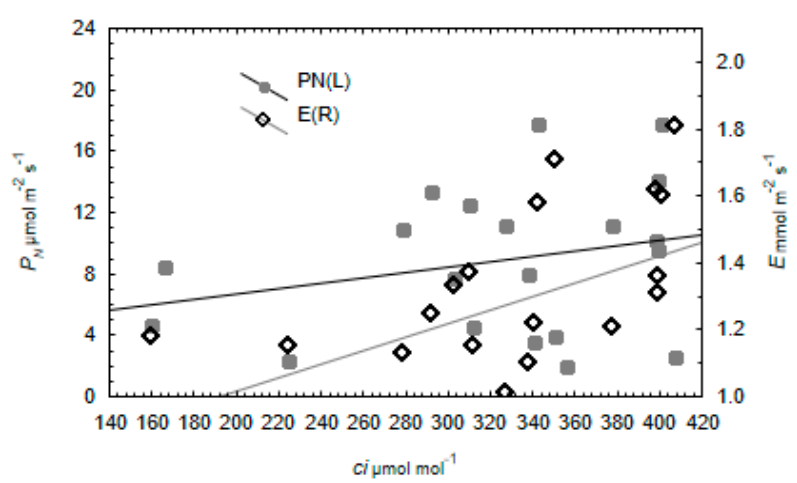

Figure 3. The relationships are based on $r$-Pearson's correlation coefficient and linear regressions between the concentration of intercellular $\mathrm{CO}_{2}(\mathrm{C} i)$ vs. photosynthetic rate $\left(P_{N}\right)$ and transpiration $(E)$ parameters at two growing stages of strawberry.

\begin{tabular}{|c|c|c|c|c|c|c|c|c|c|}
\hline Cultivar & Stage & $\begin{array}{c}g_{s} \\
\left(\mathrm{~mol} \cdot \mathrm{m}^{-2} \cdot \mathrm{s}^{-1}\right)\end{array}$ & & $\begin{array}{c}C i \\
\left(\mu \mathrm{mol} \cdot \mathrm{mol}^{-1}\right)\end{array}$ & & $\underset{\left(\mu \mathrm{mol} \cdot \mathrm{m}^{-2} \cdot \mathrm{s}^{-1}\right)}{P_{N}}$ & & $\begin{array}{c}E \\
\left(\mathrm{mmo} \cdot \mathrm{m}^{-2} \cdot \mathrm{s}^{-1}\right)\end{array}$ & \\
\hline Baron von & 1 & $0.144 \pm 0.012$ & $\mathrm{a}$ & $249.8 \pm 13.1$ & $\mathrm{a}$ & $5.80 \pm 2.36$ & $\mathrm{a}$ & $1.947 \pm 0.109$ & $\mathrm{a}$ \\
\hline Solemacher & 2 & $0.062 \pm 0.004$ & $\mathrm{~b}$ & $245.2 \pm 15.3$ & $\mathrm{a}$ & $5.02 \pm 1.91$ & $\mathrm{a}$ & $1.087 \pm 0.056$ & $\mathrm{~b}$ \\
\hline Mean & & $0.103 \pm 0.009$ & $\mathrm{~A}$ & $247.5 \pm 9.95$ & B & $5.41 \pm 1.07$ & B & $1.517 \pm 0.092$ & $\mathrm{~A}$ \\
\hline \multirow{2}{*}{ Regina } & 1 & $0.145 \pm 0.015$ & $\mathrm{a}$ & $292.9 \pm 8.65$ & $\mathrm{a}$ & $7.20 \pm 1.24$ & $\mathrm{a}$ & $1.963 \pm 0.119$ & $\mathrm{a}$ \\
\hline & 2 & $0.055 \pm 0.026$ & $\mathrm{~b}$ & $245.3 \pm 18.8$ & $\mathrm{~b}$ & $7.13 \pm 2.90$ & $\mathrm{a}$ & $0.998 \pm 0.056$ & $\mathrm{~b}$ \\
\hline Mean & & $0.100 \pm 0.004$ & $\mathrm{~A}$ & $269.1 \pm 10.9$ & $\mathrm{~A}$ & $7.17 \pm 0.96$ & $\mathrm{~A}$ & $1.480 \pm 0.101$ & $\mathrm{~A}^{1}$ \\
\hline
\end{tabular}

Table 4. Gas-exchange parameters at two growing stages (1-BBCH 61, 2-BBCH 85) of two wild strawberry cultivars.

$g_{s}$-stomatal conductance, $\mathrm{C} i$-intercellular carbon dioxide $\left(\mathrm{CO}_{2}\right)$ concentration, $P_{N}$-net photosynthetic rate, $E$ - transpiration rate;

1 various letters in rows indicate significant differences between growing stages (small letters)/cultivars (large letters) according to HSD

Tukey's test at $p=0.05$.

Coefficient of correlation ( $r$-Pearson) and linear regression described the model of two processes between the concentration of intercellular $\mathrm{CO}_{2}$ and $P_{N} / E$ parameters at two growing stages for both cultivars studied (Figure 4). At the BBCH 61 stage, significant and positive correlations were found between the concentration of intercellular $\mathrm{CO}_{2}$ and the photosynthetic rate in 'Baron von Solemacher' $(r=0.89, p<0.01$ with the slope $b=0.017)$ and in 'Regina' ( $r=0.97, p<0.001$ with the slope $b=0.002)$. Stabilization of the processes was observed between $\mathrm{C} i$ and transpiration rate, with a significant correlation between them for both cultivars at $\mathrm{BBCH} 61$ stage. A significant correlation for 'Baron von Solemacher' amounted $r=0.67, p<0.04$ with the slope $b=0.002$, and the cross point for $C_{i}=362 \mu \mathrm{mol} \mathrm{mol}^{-1}$, while for 'Regina', it has reached $C i=335 \mu \mathrm{mol} \mathrm{mol}^{-1}$. A differ- 
ent pattern for both cultivars was detected at stage $\mathrm{BBCH}$ 85. Increasing and significant correlations between $C_{i}$ and $P_{N} / E$ were reported for 'Regina' only, while for 'Baron von Solemacher', the nonsignificant negative correlation $r=-0.20$ and nonsignificant positive correlation with the $r=0.38$ were found.

'Baron von Solemacher'

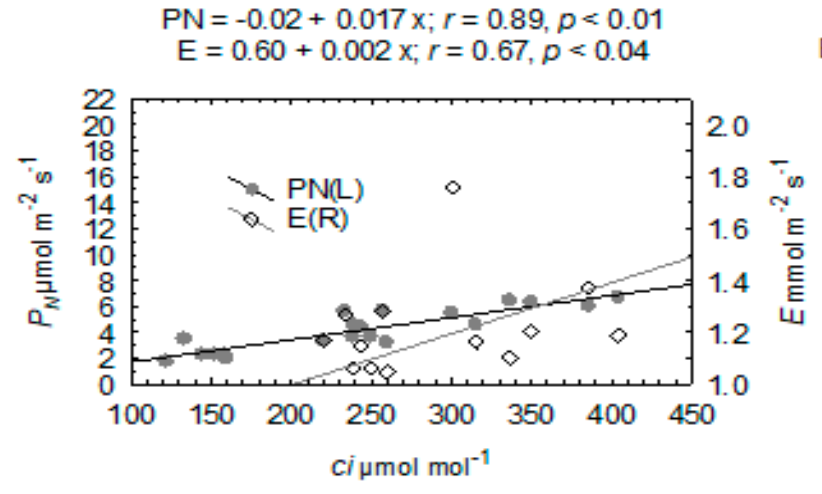

$\mathrm{PN}=-4.46+0.068 \mathrm{x} ; r=0.38, p<0.15$

$\mathrm{E}=1.19-0.0016 \mathrm{x} ; r=-0.20, p=0.40$

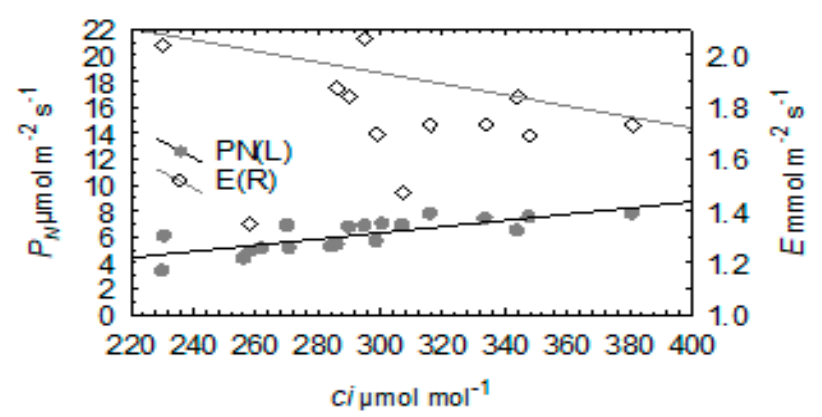

'Regina'
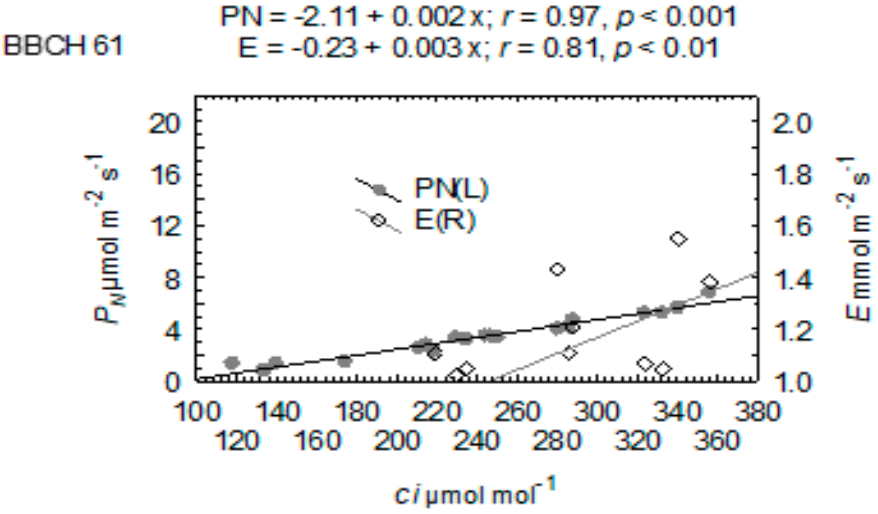

$\mathrm{BBCH} 85$

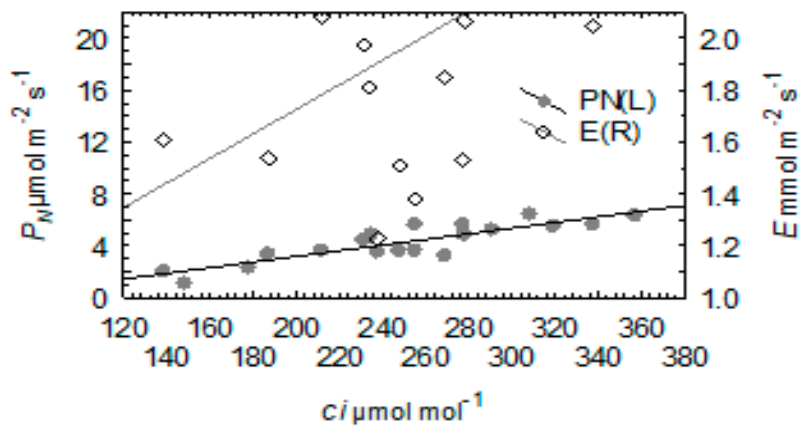

Figure 4. The relationships are based on $r$-Pearson's correlation coefficient and linear regressions between the concentration of intercellular $\mathrm{CO}_{2}(\mathrm{C} i)$ vs. photosynthetic rate $\left(P_{N}\right)$ and transpiration $(E)$ parameters at two growing stages of wild strawberry.

\subsection{Biochemical Analysis of Leaves and Fruits}

The content of anthocyanins in the fresh fruit of the investigated strawberry cultivars did not differ, but in wild strawberry, a significantly higher content of those pigments $\left(0.337 \mathrm{mg} \cdot \mathrm{g}^{-1} \mathrm{FW}\right)$ was found in the cultivar 'Regina' (Tables 5 and 6, Figure 5). The two studied strawberry cultivars differed in terms of total carbohydrate and phenolic contents. Fruits of 'Ostara' contained more carbohydrates $\left(75.35 \mathrm{mg} \cdot \mathrm{g}^{-1} \mathrm{FW}\right)$ and phenolics (7.62 mg. ${ }^{-1} \mathrm{FW}$ ) than those of 'San Andreas' (34.07 and $3.04 \mathrm{mg} \cdot \mathrm{g}^{-1} \mathrm{FW}$, respectively). On the other hand, there was no difference in total carbohydrate and phenolic concentration between the two cultivars of wild strawberry $\left(55.10-57.86 \mathrm{mg} \cdot \mathrm{g}^{-1} \mathrm{FW}\right.$ and $\left.4.85-5.26 \mathrm{mg} \cdot \mathrm{g}^{-1} \mathrm{FW}\right)$. The content of carotenoids in fresh leaves was higher in 'San Andreas' $\left(1.052 \mathrm{mg} \cdot \mathrm{g}^{-1} \mathrm{FW}\right)$ than in 'Ostara', while in wild strawberries, 'Regina' was characterized by a higher concentration of those pigments $\left(0.840 \mathrm{mg} \cdot \mathrm{g}^{-1} \mathrm{FW}\right)$ than 'Baron von Solemacher'. The strawberry 'San Andreas' had a higher content of chlorophyll $a$ and chlorophyll $b$ than 'Ostara'. On the other hand, the content of chlorophyll $a$ in the wild strawberry 'Baron von Solemacher' was significantly higher than in the cultivar 'Regina'. 


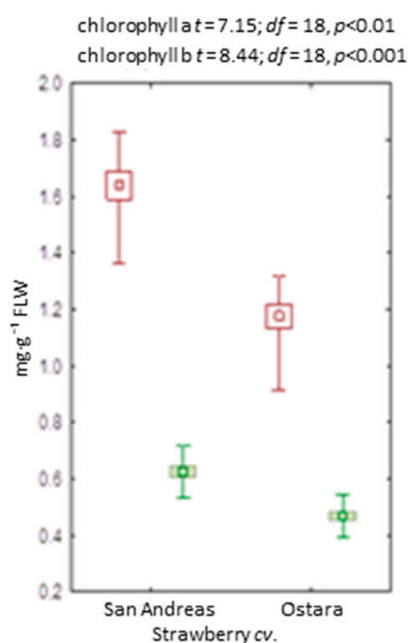

A chlorophyllat $t=3.16 ; d f=18, p<0.0$ chlorophyllb $t=1.88 ; d f=18, p>0.05$

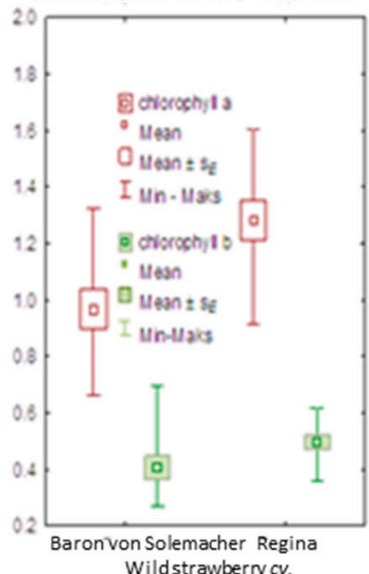

C
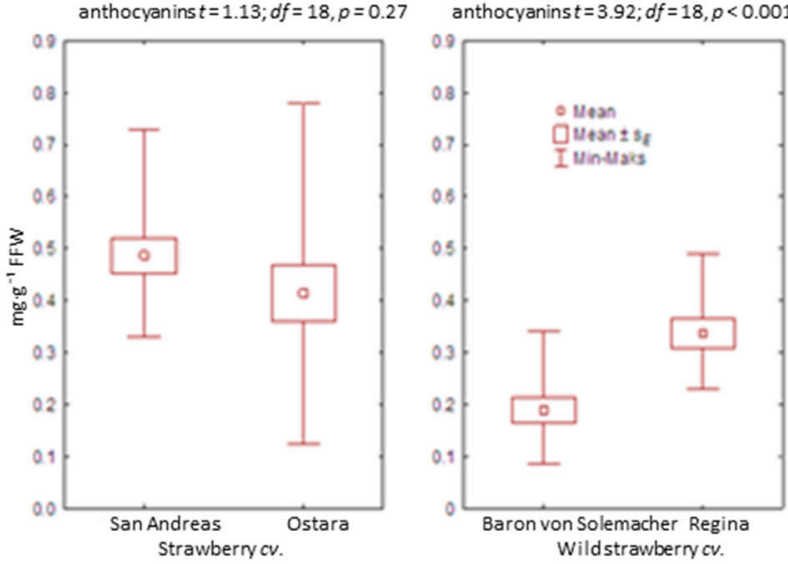

B
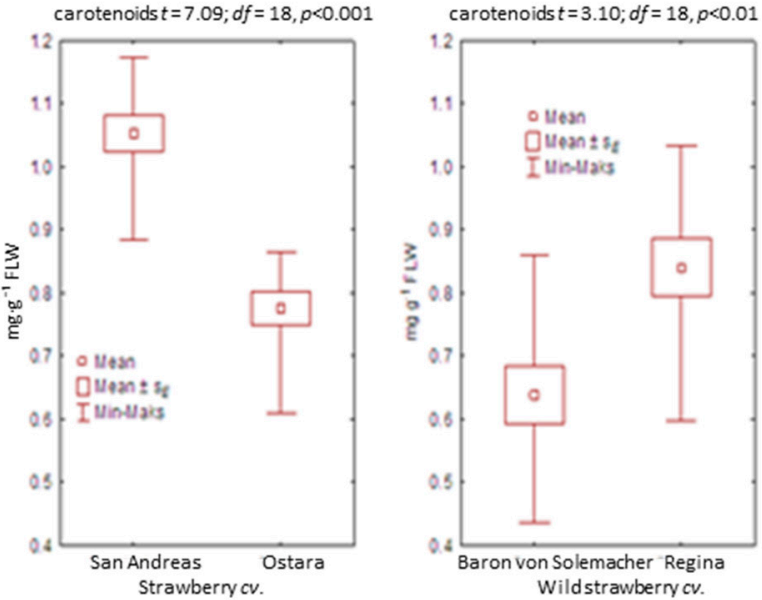

D
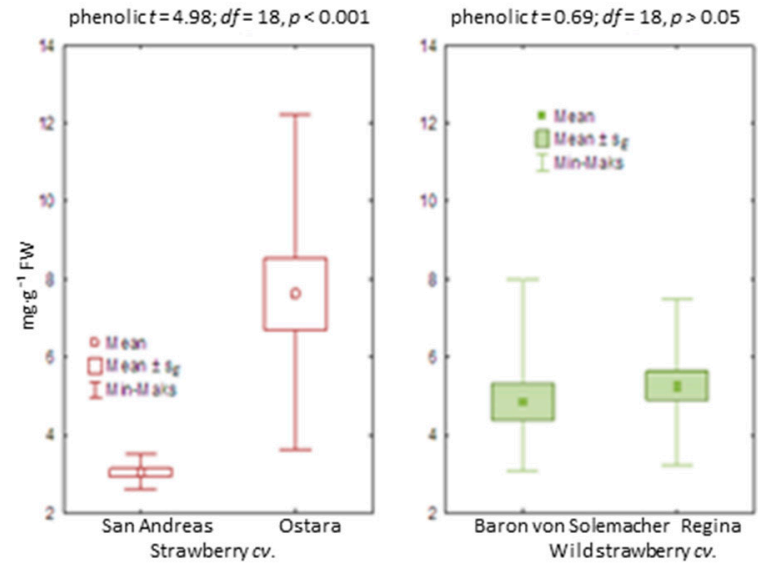

$E$
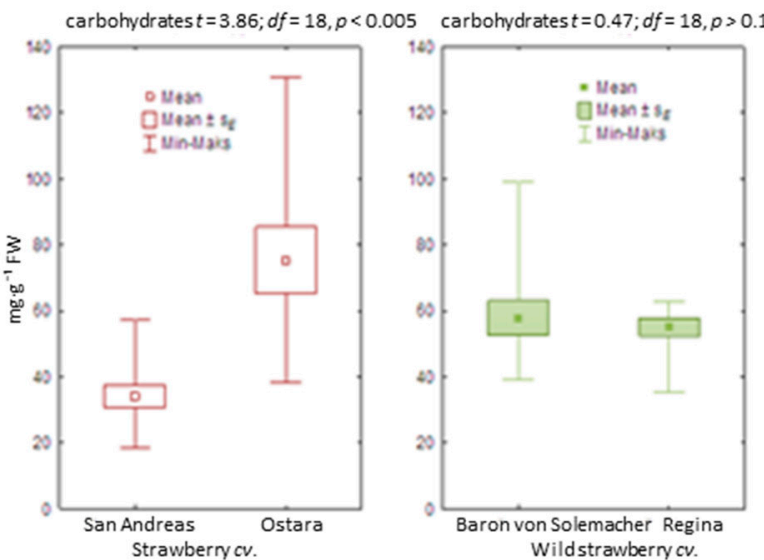

Figure 5. Box-plots of the content of chlorophylls $a$ and $b$ in fresh leaves (A), carotenoids in fresh leaves (B), anthocyanins in fresh fruits (C), phenolics in fresh fruits (D), and carbohydrates in fresh fruits (E) of strawberry and wild strawberry. 
Table 5. Contents of pigments (anthocyanins, carotenoids, chlorophyll $a$, chlorophyll $b$ ), phenolics, and carbohydrates in fresh fruits or leaves of two strawberry cultivars.

\begin{tabular}{ccccccc}
\hline \multirow{2}{*}{ Cultivar } & Anthocyanins & Phenolics & Carbohydrates & Carotenoids & Chlorophyll $\boldsymbol{a}$ & Chlorophyll $\boldsymbol{b}$ \\
\cline { 2 - 7 } & & \multicolumn{7}{c}{$\mathbf{( m g \cdot \mathbf { g } ^ { - \mathbf { 1 } } \mathbf { F W } )}$} \\
\cline { 2 - 7 } & & & & \\
San Andreas & $0.486 \pm 0.034 \mathrm{a}$ & $3.04 \pm 0.11 \mathrm{~b}$ & $34.07 \pm 3.49 \mathrm{~b}$ & $1.052 \pm 0.029 \mathrm{a}$ & $1.639 \pm 0.049 \mathrm{a}$ & $0.623 \pm 0.019 \mathrm{a}$ \\
Ostara & $0.414 \pm 0.054 \mathrm{a}$ & $7.62 \pm 0.91 \mathrm{a}$ & $75.35 \pm 10.11 \mathrm{a}$ & $0.775 \pm 0.025 \mathrm{~b}$ & $1.175 \pm 0.041 \mathrm{~b}$ & $0.467 \pm 0.014 \mathrm{~b}{ }^{1}$ \\
\hline
\end{tabular}

${ }^{1}$ Various letters in rows indicate significant differences according to the $t$-Student test at $p=0.05$.

Table 6. Contents of pigments (anthocyanins, carotenoids, chlorophyll $a$, chlorophyll $b$ ), phenolics, and carbohydrates in fresh fruits or leaves of two wild strawberry cultivars.

\begin{tabular}{|c|c|c|c|c|c|c|}
\hline \multirow{3}{*}{ Cultivar } & \multicolumn{3}{|c|}{ Fruits } & \multicolumn{3}{|c|}{ Leaves } \\
\hline & Anthocyanins & Phenolics & Carbohydrates & Carotenoids & Chlorophyll $a$ & Chlorophyll $b$ \\
\hline & \multicolumn{6}{|c|}{$\left(\mathrm{mg} \cdot \mathrm{g}^{-1} \mathrm{FW}\right)$} \\
\hline $\begin{array}{l}\text { Baron von } \\
\text { Solemacher }\end{array}$ & $0.190 \pm 0.023 b$ & $4.85 \pm 0.47 \mathrm{a}$ & $57.86 \pm 5.17 \mathrm{a}$ & $0.638 \pm 0.046 b$ & $0.965 \pm 0.071 \mathrm{a}$ & $0.404 \pm 0.041 \mathrm{a}$ \\
\hline Regina & $0.337 \pm 0.028 \mathrm{a}$ & $5.26 \pm 0.37 \mathrm{a}$ & $55.10 \pm 2.73 \mathrm{a}$ & $0.840 \pm 0.045 \mathrm{a}$ & $0.495 \pm 0.025 b$ & $0.337 \pm 0.026 \mathrm{a}^{1}$ \\
\hline
\end{tabular}

${ }^{1}$ Various letters in rows indicate significant differences according to the $t$-Student test at $p=0.05$.

\section{Discussion}

4.1. The Dynamics of Flowering and Yielding, and Biometrical Leaf Characteristic of Strawberry and Wild Strawberry in Gutter Cultivation

Comparison of the dynamics in flowering and yielding of strawberry and wild strawberry cultivars in the autumn-winter greenhouse gutter cultivation revealed higher usefulness and productivity of wild strawberry in the given conditions. Strawberry 'Ostara' failed to produce satisfying numbers of flowers developing into fruits-the yielding of this cultivar was poor. Slightly higher efficiency of mature fruit production was reported in strawberry 'San Andreas'. These differences between the tested strawberry cultivars in fruit yielding can be associated with the production of leaves with lower dry and fresh weight, as well as with lower biometrical parameters for leaf size in 'Ostara' cultivar compared to 'San Andreas'. The production of smaller leaves results in a lower photosynthetic activity and, consequently, lower available energy for the production of generative organs. The winter greenhouse experiments conducted in Iceland showed that the productivity of strawberry plants 'Sonata' and 'Elsanta' decreased constantly starting from the sixth week of cultivation [36]. As for Fragaria vesca, we observed a later decrease in fruit yield, from the 14th week after planting. Nonetheless, with wild strawberries 'Baron von Solemacher' and 'Regina', an efficient production method was developed that could be used in the autumn-winter production of this crop even in the temperate climate. Leaves of these wild berries were of similar fresh and dry weights and the dynamics of flower and mature fruit formations were more uniform in both cultivars studied.

Light intensity expressed as photosynthetic photon flux density (PPFD) is one of the crucial factors for efficient photosynthesis and considerably affects fruit production in strawberry plants [37]. In winter greenhouse cultivation, supplemental lighting is the main factor triggering flowering and yielding. Tang et al. [38] pointed the range of PPFD 387-437 $\mu \mathrm{mol} \cdot \mathrm{m}^{-2} \cdot \mathrm{s}^{-1}$ and temperature $20.5-27.4^{\circ} \mathrm{C}$ as the optimal for greenhouse 'Jingzangxiang' strawberry cultivation in a solar greenhouse. According to Hidaka et al. [37], the cultivation light saturation point for strawberries in the greenhouse was observed at $25{ }^{\circ} \mathrm{C}$ at PPFD $400 \mu \mathrm{mol} \mathrm{m}{ }^{-2} \mathrm{~s}^{-1}$. In the present study, the mean PPFD was lower, i.e., $100 \mu \mathrm{mol} \mathrm{m}^{-2} \mathrm{~s}^{-1}$, which could contribute to the lower leaf size and fruit yield in F. ananassa. Hidaka et al. [39] reported the highest fruit yield in the winter season cultivation under LED light supplementation at PPFD $400 \mu \mathrm{mol} \cdot \mathrm{m}^{-2} \cdot \mathrm{s}^{-1}$ measured $10 \mathrm{~cm}$ above the substrate surface. Perhaps using this light source with a higher PPFD value in the present 
study, which also has several other benefits, could contribute to the elevated biometrical parameters of leaves and, consequently, in higher fruit yielding of strawberry. Because wild strawberry demand for light is lower [40], their leaves and fruits could yield better and more uniformly than strawberries in our experiment.

\subsection{Physiological Response of Strawberry and Wild Strawberry}

Gas exchange regulation is of great importance for water balance and the uptake of $\mathrm{CO}_{2}$. Controlling $g_{s}$ is a complex process that depends on the water potential in leaves and on the intensity of transpiration, as well as on such factors as the gradients of $\mathrm{CO}_{2}$ concentration or the quality and intensity of light [41-44]. Our research demonstrated that the plants of two cultivars of strawberry and wild strawberry species, at two BBCH (61 and 85) stages, display different $g_{s}$ changes after 15 days. This prevented the inhibition of photosynthesis in 'San Andreas' leaves with the significantly decreased intensity of assimilation, due to the accompanying increase of intercellular $\mathrm{CO}_{2}$ concentration and slight fluctuations of the value of $g_{s}$, which pointed to the nonstomatal limitation of photosynthesis. A study by Keutgen et al. [45] shows that the transpiration and stomata conductivity in the strawberry cultivar 'Elsanta' was significantly influenced by the age of the leaves. The reduction of net photosynthetic rate was less distinct in young leaves exposed to $\mathrm{CO}_{2}$ levels above 600 ppm for less than three weeks, indicating that the reduction might depend on the period of exposition or leaf age. Moreover, the gas exchange research by Martins de Lime et al. [2] showed that planting spacing of 'Pircinque' strawberry above $20 \mathrm{~cm}$ disrupts the availability of $\mathrm{CO}_{2}$, making the cultivation less productive.

Koziołek et al. [46] also described various stomatal conductance changes in leaves of shy plant (Mimosa pudica L.) due to abiotic factors, e.g., after thermal and light stimulation. The reaction after such stimulation on one part of the leaf showed a variable $g_{s}$ pattern for the neighboring leaf part in the system of open and rolled pinnules after touching. According to Hinckley and Braatne [47], stomatal conductance is inversely correlated with the concentration of $\mathrm{CO}_{2}$ in leaves if tissues are adequately irrigated. Nardini et al. [48] show linear dependence between gas exchange and water vapor conductance and the parameters are closely correlated with each other $\left(r^{2}=0.987, p<0.01\right)$. We found a stronger positive correlation between $P_{N}$ and $C i$ at two growth stages ( $r$ from 0.56 to 0.70 ) for 'San Andreas' plants, which attributed this cultivar to the conditions of growth and better production of biomass. Photosynthesis and transpiration are usually correlated with each other because stomata determine the conductance of water vapor and carbon dioxide [49].

Although genetic differences in photosynthetic capacity exist at intraspecific and interspecific levels, $P_{N}$ is considered as one of the potential, physiological indicators for screening of drought tolerance of cultivars or species [50]. A physiological performance of plants exposed to drought stress results in the reduction of $P_{N}$ and $g s$ values, which are directly related to the performance of the leaf morphological traits because better leaf morphology and vegetative growth help to capture more light that results in the higher efficacy of the $P_{N}$ [51]. In our study, the photosynthetic rate amounted to $13.0 \mu \mathrm{mol} \mathrm{m}^{-2} \mathrm{~s}^{-1}$ for 'San Andreas' and $7.25 \mu \mathrm{mol} \mathrm{m} \mathrm{m}^{-2} \mathrm{~s}^{-1}$ for 'Ostara' and was significantly higher in 'San Andreas' strawberry cultivar, which confirms the higher fruit productivity of 'San Andreas'. Similarly, the content of carotenoids and chlorophylls $a$ and $b$ was higher in 'San Andreas' than in 'Ostara'. Moreover, $P_{N}$ and carotenoid content in 'Regina' wild strawberry was significantly higher than in 'Baron von Solemacher'; however, this did not affect the productivity of these cultivars.

\subsection{Biochemical Analysis of Leaves and Fruits}

The antioxidant activity of strawberry and other members of the Rosaceae family has been positively correlated with anthocyanin content in the fruits [4]. Our study has shown that strawberries and wild strawberries grown in controlled greenhouse conditions on coconut mats in gutters in the autumn-winter season, irradiated with sodium lamps, give a rather high anthocyanins content, reaching up to $0.486 \mathrm{mg} \mathrm{g}^{-1}$ in the fresh fruit 
weight in 'San Andreas' cultivar. In the study by Aaba et al. [52], concerning 27 cultivars of strawberry that were cultivated by applying conventional farming practice for growing in the open air, the content of anthocyanins varied from 0.085 to $0.659 \mathrm{mg} \cdot \mathrm{g}^{-1} \mathrm{FW}$, depending on the cultivar. As for wild strawberry 'Regina', we found a significantly higher content of anthocyanins $\left(0.337 \mathrm{mg} \cdot \mathrm{g}^{-1}\right)$ than in 'Baron von Solemacher', which proves a significant influence of the genotype. This is also confirmed by Krüger et al. [53], who found that the total anthocyanin concentration in strawberry is both qualitatively and quantitatively known to be strongly influenced by the genotype and, likewise, by external factors such as temperature and light (photoperiod, quantity, and wavelength including UV-light).

Controlled conditions in the greenhouse have an advantage over traditional field cultivation due to the elimination of the influence of year-to-year climatic variation on the strawberry quality. It was reported that strawberries are UV-unresponsive regarding the content of total anthocyanins and total phenols [54]. Therefore, the biosynthesis of these important secondary metabolites is not limited in greenhouse cultivation. On the other hand, little is known about gutter cultivation effects on the quantitative changes in the content of total polyphenols in (wild) strawberry fruits. Our results showed that the content of phenolic compounds was significantly higher in strawberry 'Ostara' $\left(7.62 \mathrm{mg} \cdot \mathrm{g}^{-1} \mathrm{FW}\right)$ than in 'San Andreas' (3.04 mg.g $\left.{ }^{-1} \mathrm{FW}\right)$, whereas the tested wild strawberry cultivars did not differ among each other in this regard $\left(5.26 \mathrm{mg} \cdot \mathrm{g}^{-1} \mathrm{FW}\right.$ in 'Regina' and $4.85 \mathrm{mg} \cdot \mathrm{g}^{-1}$ FW in 'Baron von Solemacher'). Based on the study by Bojarska et al. [55], it was found that the content of total phenolic compounds in 11 strawberries cultivars grown in a field, in Poland, ranged from 4.97 to $7.88 \mathrm{mg} \cdot \mathrm{g}^{-1} \mathrm{FW}$, while the content of anthocyanins was at the level of $0.030 \mathrm{up}$ to $0.071 \mathrm{mg} \cdot \mathrm{g}^{-1} \mathrm{FW}$. In the present study, the anthocyanins and phenols content was comparable or relatively higher compared to other strawberry cultivars grown under traditional cultivation in open-air conditions. Phenols and anthocyanins are secondary metabolites with antioxidant properties that commonly occur in many edible plant organs and are beneficial for human health. The presence of these components determines the quality, nutritional value, and sensorial properties of fruits. The activity of enzymes involved in their biosynthesis is influenced by many environmental factors, particularly by light intensity and light spectrum (red, blue, UVB) [19,56]. Moreover, the biosynthesis of different phenolic compounds depends on the plant genotype and cultivation conditions [57]. Thus, it can be assumed that controlled greenhouse conditions and cultivation period used in the present study favored the accumulation of valuable metabolites in the tested strawberry and wild strawberry cultivars, increasing the pro-health values of their fruits.

The carbohydrate content reveals the rate of metabolic activity and state of plant development [58]. Sucrose represents the carbon skeleton of a plant cell and plays a significant role in promoting the cell cycle and organogenesis [59]. It also determines the taste of the crop. The tested strawberry cultivar 'Ostara' synthesized more carbohydrates (75.35 mg.g ${ }^{-1} \mathrm{FW}$ ) than 'San Andreas' (34.07 mg.g $\left.{ }^{-1} \mathrm{FW}\right)$. In contrast, no significant differences were found between the tested wild strawberry cultivars-fruits of 'Regina' and 'Baron von Solemacher' contained $55.10 \mathrm{mg} \cdot \mathrm{g}^{-1} \mathrm{FW}$ and $57.86 \mathrm{mg} \cdot \mathrm{g}^{-1} \mathrm{FW}$ of carbohydrates, respectively. The obtained values are comparable to those found in fresh fruits by other authors [60] which means that the gutter cultivation during the autumn-winter season does affect this important trait.

\section{Conclusions}

Strawberry and wild strawberry cultivars grown in the same controlled greenhouse conditions on coconut mats in gutters in the autumn-winter period in Poland, irradiated with sodium lamps, demonstrate different physiological, biochemical, and biometrical responses, which proves a significant influence of the genotype factor. Wild strawberry is more suitable for gutter cultivation than strawberry. Among the four cultivars studied, 'San Andreas' (strawberry) and 'Regina' (wild strawberry) responded more favorably to the given greenhouse conditions in terms of leaf biometric parameters, gas-exchange 
parameters, and some biochemical characteristics. This indicates that these cultivars are more suitable for cultivation in gutters under controlled greenhouse conditions in the autumn-winter season. The reason why 'Ostara' showed the lower growth habits is due to the genetic background of the everbearing habit. However, more research in regard to lighting conditions and fertigation is needed to improve fruit production, especially in strawberry. Additional day-neutral cultivars should also be tested. Nonetheless, despite the limited yield of strawberry, a high nutritional value of fruits is maintained.

Author Contributions: Conceptualization, A.W.-P. and J.L.-R.; methodology, J.L.-R., A.W.-P., D.K. and A.T.; validation, formal analysis A.W.-P., J.L.-R. and N.M.; investigation, data curation, D.K., J.L.-R., N.M., A.T. and A.W.; writing-original draft preparation J.L.-R., D.K., A.T., A.W.-P. and N.M.; writing-review and editing, visualization, J.L.-R., N.M., A.W.-P. and D.K.; supervision, project administration, funding acquisition, J.L.-R. and A.W.-P. All authors have read and agreed to the published version of the manuscript.

Funding: This research was funded by the Faculty of Agriculture and Biotechnology, UTP University of Science and Technology in Bydgoszcz, Poland (No. 1/2020).

Institutional Review Board Statement: Not applicable.

Informed Consent Statement: Not applicable.

Data Availability Statement: The data presented in this study are available on request from the corresponding author.

Acknowledgments: The authors would like to thank: Mateusz Nowakowski, Ariel Langowski, and Alicja Pawlak, for their technical assistance in performing the experiments.

Conflicts of Interest: The authors declare no conflict of interest.

\section{References}

1. Skrovankova, S.; Sumczynski, D.; Mlcek, J.; Jurikova, T.; Sochor, J. Bioactive compounds and antioxidant activity in different types of berries. Int. J. Mol. Sci. 2015, 16, 24673-24706. [CrossRef]

2. Martins de Lima, J.; Welter, P.D.; Soares dos Santos, M.F.; Kavcic, W.; Costa, B.M.; Fagherazzi, A.F.; Nerbass, F.R.; Kretzschmar, A.A.; Rufato, L.; Baruzzi, G. Planting density interferes with strawberry production efficiency in Southern Brazil. Agronomy 2021, 11, 408. [CrossRef]

3. Food and Agriculture Organization of the United Nations. Available online: http://www.fao.org/faostat/en/\#data/QC/ visualize (accessed on 16 July 2021).

4. Wang, S.Y.; Lin, H.S. Antioxidant activity in fruits and leaves of blackberry, raspberry, and strawberry varies with cultivar and developmental stage. J. Agric. Food Chem. 2000, 48, 140-146. [CrossRef]

5. Ulrich, D.; Olbricht, K. Diversity of volatile patterns on sixteen Fragaria vesca L. accessions in comparison to cultivars of Fragaria $\times$ ananassa. J. Appl. Bot. Food Qual. 2013, 86, 37-46. [CrossRef]

6. Mozafari, A.; Havas, S.; Ghaderi, N. Application of iron nanoparticles and salicylic acid in in vitro cultures of strawberries (Fragaria $\times$ ananassa Duch.) to cope with drought stress. Plant Cell Tiss. Org. Cult. 2018, 132, 511-523. [CrossRef]

7. Chiomento, J.L.T.; Lima, E.P.; D'Agostini, M.; Stockmans De Nardi, F.; Tretin, T.; Grando Dornelles, A.; Huzar-Novakowiski, J.; Calvete, E.O. Horticultural potential of nine strawberry cultivars by greenhouse production in Brazil: A view through multivariate analysis. Sci. Hortic. 2021, 279, 109738. [CrossRef]

8. Andersen, Ø.M.; Fossen, T.; Torskangerpoll, K.; Fossen, A.; Hauge, U. Anthocyanin from strawberry (Fragaria ananassa) with the novel aglycone, 5-carboxypyranopelargonidin. Phytochemistry 2004, 65, 405-410. [CrossRef] [PubMed]

9. Palha, M.G.S. Strawberry growth and development in the mild winter european regions. Int. J. Fruit Sci. 2005, 5, 83-90. [CrossRef]

10. Heide, O.M.; Stavang, J.A.; Sønsteby, A. Physiology and genetics of flowering in cultivated and wild strawberries-A review. J. Hortic. Sci. Biotechnol. 2013, 88, 1-18. [CrossRef]

11. Khoshnevisan, B.; Shariati, H.M.; Rafii, S.; Mousazadeh, H. Comparison of energy consumption and GHG emissions of open field and greenhouse strawberry production. Renew. Sustain. Energy Rev. 2014, 29, 316-324. [CrossRef]

12. Chiomento, J.L.T.; Ferreira, A.F.B.; Costa, R.C.; Tretin, N.; Tretin, T.; Calvete, E.O. Phyllochron, and root system development of six strawberry cultivars with different photoperiodic flowering responses. Sci. Agrar. Parana. 2020, 19, 368-373.

13. Miranda, F.R.; Silva, V.B.; Santos, F.S.R.; Rossetti, G.; Silva, C.F.B. Production of strawberry cultivars in closed hydroponic systems and coconut fibre substrate. Rev. Ciênc. Agron. 2014, 45, 833-841. [CrossRef]

14. Galati, A.; Sabatino, L.; Prinzivalli, C.S.; D'Anna, F.; Scalenghe, R. Strawberry fields forever: That is, how many grams of plastics are used to grow a strawberry? J. Environ. Manag. 2020, 276, 111313. [CrossRef] 
15. Ahn, M.G.; Kim, D.S.; Ahn, S.R.; Sim, H.S.; Kim, S.; Kim, S.K. Characteristics and trends of strawberry cultivars throughout the cultivation season in a greenhouse. Horticulturae 2021, 7, 30. [CrossRef]

16. Claire, D.; Watters, N.; Gendron, L.; Boily, C.; Pépin, S.; Caron, J. High productivity of soilless strawberry cultivation under rain shelters. Sci. Hortic. 2018, 232, 127-138. [CrossRef]

17. Costa, R.C.; Calvete, E.O.; Mendonca, H.F.C.; Cecatto, A.P. Phenology, phyllochron, and gas exchanges in frigo and fresh strawberry (Fragaria $\times$ ananassa Duch.) plants of cv. Albion. Aust. J. Crop. Sci. 2014, 8, 901-908.

18. Choi, H.G.; Moon, B.Y.; Kang, N.J. Effects of LED light on the production of strawberry during cultivation in a plastic greenhouse and in a growth chamber. Sci. Hortic. 2015, 189, 22-31. [CrossRef]

19. Michalska, A.; Carlen, C.; Heritier, J.; Andlauer, W. Profiles of bioactive compounds in fruits and leaves of strawberry cultivars. J. Berry Res. 2017, 7, 71-84. [CrossRef]

20. Aarti, P.D.; Tanaka, R.; Tanaka, A. Effects of oxidative stress on chlorophyll biosynthesis in cucumber (Cucumis sativus) cotyledons. Phys. Plant 2006, 128, 186-197. [CrossRef]

21. Ruiz-Sola, M.; Rodríguez-Concepción, M. Carotenoid biosynthesis in Arabidopsis: A colorful pathway. TAB 2012, 10, 158-185. [CrossRef] [PubMed]

22. Bhusal, N.; Bhusal, S.J.; Yoona, T.-M. Comparisons of physiological and anatomical characteristics between two cultivars in bi-leader apple trees (Malus $\times$ domestica Borkh.). Sci. Hortic. 2018, 231, 73-81. [CrossRef]

23. Vemmos, S.N.; Petri, E.; Stournaras, V. Seasonal changes in photosynthetic activity and carbohydrate content in leaves and fruit of three fig cultivars (Ficus carica L.). Sci. Hortic. 2013, 169, 198-207. [CrossRef]

24. Havaux, M. Carotenoid oxidation products as stress signals in plants. Plant J. 2014, 79, 597-606. [CrossRef]

25. Savchenko, T.; Tikhonov, K. Oxidative Stress-Induced Alteration of Plant Central Metabolism. Life 2021, 11, 304. [CrossRef]

26. İnanç, A.L. Chlorophyll: Structural properties, health benefits and its occurrence in virgin olive oils. Akad. Gıda 2011, 9, 26-32.

27. Fiedor, J.; Burda, K. Potential role of carotenoids as antioxidants in human health and disease. Nutrients 2014, 6, 466-488. [CrossRef] [PubMed]

28. Paul, M.J.; Foyer, C.H. Sink regulation of photosynthesis. J. Exp. Bot. 2001, 52, 1383-1400. [CrossRef] [PubMed]

29. Masny, A.; Żurawicz, E. Season extension possibilities in two polish june-bearing strawberry cultivars. Acta Sci. Pol. Hortorum Cultus 2015, 14, 115-127.

30. Lema-Rumińska, J.; Zalewska, M. Studies on flower pigments of chrysanthemum mutants: Nero and Wonder groups. Acta Sci. Pol. Hortorum Cultus 2004, 3, 125-135.

31. Wettstein, D. Chlorophyll-letale und der submikroskopische Formwechsel der Plastiden. Exp. Cell Res. 1957, 12, 427-506. [CrossRef]

32. Harborne, J.B. Comparative biochemistry of the flavonoids. Phytochemistry 1967, 6, 1569-1573. [CrossRef]

33. Lichtenthaler, H.K.; Buschmann, C. Chlorophylls and carotenoids: Measurement and characterisazacion by UV-VIS Spectroscopy. In Current Protocols in Food Analytical Chemistry; Wiley: Hoboken, NJ, USA, 2001; Units F4.3.1-F4.3.8. [CrossRef]

34. Trevelyan, W.E.; Forrest, R.S.; Harrison, J.S. Determination of yeast carbohydrates with the anthrone reagent. Nature 1952, 170, 626-627. [CrossRef]

35. Waterhouse, A.L. Determination of total phenolics. In Current Protocols in Food Analytical Chemistry; Wrolstad, R.E., Ed.; John Wiley \& Sons: New York, NY, USA, 2001; pp. I1.1.1-I1.1.8. [CrossRef]

36. Stadler, C. Effect of light intensity on yield of winter grown strawberries in Iceland. DGG Proc. 2017, 7, 1-5. [CrossRef]

37. Hidaka, K.; Ito, E.; Sago, Y.; Yasutake, D.; Miyoshi, Y.; Kitano, M.; Miyauchi, K.; Okimura, M.; Imai, S. High yieldsof strawberry by applying vertically-moving beds on the basis of leaf photosynthesis. Environ. Control Biol. 2012, 50, 143152. [CrossRef]

38. Tang, Y.; Ma, X.; Li, M.; Wang, Y. The effect of temperature and light on strawberry production in a solar greenhouse. Solar Energy 2020, 195, 318-328. [CrossRef]

39. Hidaka, K.; Dan, K.; Imamura, H.; Miyoshi, Y.; Takayama, T. Effect of supplemental lighting from different light sources on growth and yield of strawberry. Environ. Control Biol. 2013, 51, 41-47. [CrossRef]

40. Nin, S.; Petrucci, W.A.; Giordani, E.; Marinelli, C. Soilless systems as an alternative to wild strawberry (Fragaria vesca L.) traditional open-field cultivation in marginal lands of the Tuscan Apennines to enhance crop yield and producers' income. J. Hortic. Sci. Biotech. 2017, 93, 1-13. [CrossRef]

41. Mott, K.A.; Parkhurst, D.F. Stomatal responses to humidity in air and helox. Plant Cell Environ. 1991, 14, 509-515. [CrossRef]

42. Sperry, J.S.; Pockman, W.T. Limitation of transpiration by hydraulic conductance and xylem cavitation in Betula occidentalis. Plant Cell Environ. 1992, 16, 279-287. [CrossRef]

43. Messinger, S.M.; Buckley, T.N.; Mott, K.A. Evidence for involvement of photosynthetic processes in the stomatal response to $\mathrm{CO}_{2}$. Plant Physiol. 2006, 140, 771-778. [CrossRef]

44. Shimazaki, K.I.; Doi, M.; Assmann, S.M.; Kinoshita, T. Light regulation of stomatal movement. Annu. Rev. Plant Biol. 2007, 58, 219-247. [CrossRef] [PubMed]

45. Keutgen, N.; Chen, K.; Lenz, F. Responses of strawberry leaf photosynthesis, chlorophyll fluorescence and macronutrient contents to elevated $\mathrm{CO}_{2}$. J. Plant Physiol. 1997, 150, 395-400. [CrossRef]

46. Koziołek, C.; Grams, T.E.E.; Schreiber, U.; Matyssek, R.; Fromm, J. Transient knockout of photosynthesis mediated by electrical signals. New Phytol. 2004, 161, 715-722. [CrossRef] [PubMed] 
47. Hinckley, T.M.; Braatne, J.H. Stomata. In Plant_Environment Interactions; Wilkinson, R.E., Ed.; Marcel Dekker Inc.: New York, NY, USA, 1994; pp. 323-355.

48. Nardini, A.; Salleo, S.; Raimondo, F. Changes in leaf hydraulic conductance correlate with leaf vein embolism in Cercis siliquastrum L. Trees 2003, 17, 529-534. [CrossRef]

49. Farquhar, G.D.; Sharkey, T.D. Stomatal conductance and photosynthesis. Ann. Rev. Plant Physiol. 1982, 33, 317-345. [CrossRef]

50. Ashraf, M.; Harris, P.J.C. Photosynthesis under stressful environments: An overview. Photosynthetica 2013, 51, 163-190. [CrossRef]

51. Bhusal, N.; Lee, M.; Lee, H.; Adhikari, A.; Han, A.H.; Han, A.; Kim, H.S. Evaluation of morphological, physiological, and biochemical traits for assessing drought resistance in eleven tree species. Sci. Total Environ. 2021, 779, 146466. [CrossRef]

52. Aaby, K.; Mazur, S.P.; Nes, A.; Skrede, G. Phenolic compounds in strawberry (Fragaria $\times$ ananassa Duch.) fruits: Composition in 27 cultivars and changes during ripening. Food Chem. 2012, 132, 86-97. [CrossRef]

53. Krüger, E.; Will, F.; Kumar, K.; Celejewska, K.; Chartier, P.; Masny, A.; Mott, D.; Petit, A.; Savini, G.; Sønsteby, A. Influence of Post-Flowering Climate Conditions on Anthocyanin Profile of Strawberry Cultivars Grown from North to South Europe. Appl. Sci. 2021, 11, 1326. [CrossRef]

54. Josuttis, M.; Dietrich, H.; Treutter, D.; Will, F.; Linnemannstöns, L.; Krüger, E. Solar UVB response of bioactives in strawberry (Fragaria $\times$ ananassa Duch.): A comparison of protected and open-field cultivation. J. Agric. Food Chem. 2010, 58, 12692-12702. [CrossRef]

55. Bojarska, J.E.; Czaplicki, S.; Zarecka, K.; Zadernowski, R. Związki fenolowe owoców wybranych odmian truskawki. Żywność Nauka Technol. Jakość 2006, 2, 20-27.

56. Cocetta, G.; Casciani, D.; Bulgari, R.; Musante, F.; Kołton, A.; Rossi, M.; Ferrante, A. Light use efficiency for vegetables production in protected and indoor environments. Eur. Phys. J. Plus 2017, 132, 43. [CrossRef]

57. Aaby, K.; Remberg, S.V. Strawberry phenolics and impact of ripening. In Processing and Impact an Active Components in Food; Preedy, V., Ed.; Elsevier: London, UK, 2015; pp. 157-164. [CrossRef]

58. Trouvelot, S.; Heloir, M.; Poinssot, B.; Gauthier, A.; Paris, F.; Guillier, C.; Combier, M.; Trda, L.; Daire, X.; Adrian, M. Carbohydrates in plant immunity and plant protection: Roles and potential application as foliar sprays. Front. Plant Sci. 2014, 5, 592. [CrossRef] [PubMed]

59. Horacio, P.; Martinez-Noel, G. Sucrose signaling in plants: A world yet to be explored. Plant Signal. Behav. 2013, 8, e23316. [CrossRef] [PubMed]

60. Kunachowicz, H.; Przygoda, B.; Nadolna, I.; Iwanow, K. Tabele Składu i Wartości Odżywczej Żywności; PWZL Wydawnictwo Lekarskie: Warsaw, Polska, 2017; p. 628. 